\title{
Postcolonial France: Immigration and the de-centring of the Hexagon
}

In a recent article Charles Forsdick analyses the unwillingness of the French academy to embrace theories of the postcolonial, and links it to the extensive debates which have taken place regarding French colonial history and its memorial afterlives. ${ }^{1}$ For Forsdick, the French reluctance to address the implications of the major population displacements of the twentieth century, from the First World War to the migration precipitated by decolonisation, is indicative of the centralising, universalising logic of French republicanism. One consequence of this ideology has been the refusal of the demands of minority groups, whose desire for recognition of their specificities in terms of gender, sexual orientation or ethnicity has been rejected on the grounds of 'communitarianism', a disparaging label associated with the Anglo-Saxon model of integration. In contrast, the republican model sees French national identity as formed through the officially sanctioned processes driven by education, legislation, an insistence on secularism and, most recently, by direct government intervention in the form of Nicolas Sarkozy's creation in 2007 of a 'Ministère de l'immigration, de l'intégration, de l'identité nationale et du codéveloppement'.

The French emphasis on republican thought has ensured that, despite the country's imperial history, research into questions of postcoloniality has been dominated by Anglophone scholars. ${ }^{2}$ Their focus has often broadly been on the need to recover the voices and experience of formerly colonised peoples, rather than emphasising any reassessment of the implications of the postcolonial for the imperial centre. This is hardly surprising, given the desire to move beyond a dichotomy in which the imperial motherland is located at the centre of the power structure, with the former colonies as

\footnotetext{
${ }^{1}$ Charles Forsdick, 'Colonial history, postcolonial memory: contemporary perspectives', Francophone Postcolonial Studies 5.2 (2007), 101-118.

2 As Forsdick points out, there are now signs that this is changing, beginning with the sesquicentenary of the abolition of slavery in 1998, and supported by the work of the Association pour la Connaissance de l'Histoire de l'Afrique Contemporaine (ACHAC), which includes La Fracture coloniale (2005), Culture post-coloniale (2006) and La Colonisation française (2007).
} 
distant peripheral satellites. Within the discipline of French studies, the lack of enthusiasm for the postcolonial has meant that issues of colonial identity have largely been studied under the auspices of Francophone studies. One of the corollaries of the rise of Francophone studies has been the development of two, often quite separate, fields of enquiry, leading to ongoing debates around the relationship between the French and the Francophone, debates now evidenced in the revised titles of many university departments of 'French and Francophone Studies'. A second consequence of this division has been the restriction of investigations of (post)colonial identity to the geographical remit of la Francophonie, to the exclusion of metropolitan France. Accordingly, much of the work which has been directed towards understanding colonialism and its aftermath has overlooked its effects on the Hexagon. ${ }^{3}$ Where research has been undertaken into contemporary France, it has tended to concentrate on the cultures of minority groups living within the métropole. ${ }^{4}$

While detailed attention to the cultures and identities of minority groups is clearly long overdue, to concentrate exclusively on them risks overlooking the extent to which the imperial centre is also fragmented and plural. Within postcolonialism, there has, at times, been the implicit suggestion that what is dominant must also be unified. ${ }^{5}$ In practice, as Raymond Williams reminds us, the lived experience of hegemony can never be singular, because it is continually challenged by pressures that require it to be repeatedly renewed and modified. ${ }^{6}$ Williams' work serves as a reminder that society and culture have always been plural, consisting of a series of competing discourses and counter-narratives which are selectively incorporated into a hegemonic tradition. The apparent unity of the hegemonic exemplifies the gap which exists between the 'hard'

\footnotetext{
${ }^{3}$ Notable exceptions include the work of Charles Forsdick and David Murphy. See, for example, David Murphy and Alec G. Hargreaves, eds, 'New Directions in Postcolonial Studies', special issue of Journal of Postcolonial Writing, 44.3 (Sept 2008); Charles Forsdick and David Murphy, eds, 'France in a Postcolonial Europe: history, memory, identity', special issue of Francophone Postcolonial Studies, 5.2 (Autumn/Winter 2007); Francophone Postcolonial Studies: A Critical Introduction, ed. by Charles Forsdick and David Murphy (London: Arnold, 2003).

${ }^{4}$ See, for example, Post-colonial Cultures in France, ed. by Alec G. Hargreaves and Mark McKinney (London: Routledge, 1997).

${ }^{5}$ See, for example, Homi Bhabha's critique of Edward Said in 'The Other Question: Difference, Discrimination and the Discourse of Colonialism,' in Literature, Politics and Theory: Papers from the Essex Conference 1976-84, pp. 210-229, ed. by Francis Barker, Peter Hulme, Margaret Iversen and Diana Loxley (London \& New York: Methuen, 1986), p. 158.

${ }^{6}$ Raymond Williams, Marxism and Literature (Oxford: Oxford University Press, 1977), p. 112.
} 
discourses of collective identity which operate in certain public spheres, and which contribute to the assumption that the imperial centre is unified, and the 'soft' identities which are acknowledged to be fluid and constructed. If, as scholars, we talk of a unified 'French identity', it is on the basis of a tacit suspension of disbelief, a state into which we agree to enter in order to participate in a politico-legal system which is not interested in the extent to which identities are provisional, and often contested.

Williams identifies various sources of challenge to the cultural dominant, pointing to the way in which hegemonic norms are altered by residual and emergent cultural elements, and affected by institutions and formations. The latter he identifies as being made up of conscious literary, artistic, philosophical or scientific movements. ${ }^{7}$ While the role of writers and artists in analysing systems of representation and identity processes at work in France's former colonies has long been recognised, less attention has been paid to the literature dealing with issues of postcoloniality, produced by Hexagonal writers. This chapter offers an intervention in this arena through the examination of a text by one such contemporary author, Dominique Bona. The work of these authors is all the more important because, although postcolonial theory is now receiving a tentative welcome in France, writers from white, metropolitan France have for some time been reflecting on the effects of decolonisation and postcolonial immigration, and the contemporary transformations which consequently are being enacted within the Hexagon. Their work draws attention to the extent to which metropolitan identities are fragmented and fluid, their organising principles subject to the evolution in social meanings and values, which Williams calls 'structures of feeling, 8

\section{Tradition and Françoise Sagan's Bonjour tristesse}

\footnotetext{
${ }^{7}$ Williams, Marxism and Literature, p. 119.

${ }^{8}$ Williams, Marxism and Literature, p. 132.
} 
In her novel, Malika, Bona uses a two-fold strategy to explore the fragmented nature of hegemonic French culture. ${ }^{9}$ On a structural level she draws on an earlier literary text to demonstrate that the plurality which characterises French society in the 1990s has not changed in the last fifty years, although the subject of society's concerns has evolved. On a thematic level, she traces the way in which metropolitan culture is destabilised by reactions to immigration, in particular the phenomenon of postcolonial immigration which John Ball has referred to as 'the reinvasion of the centre'. ${ }^{10}$ To turn first to the question of structure, Williams' analysis of tradition is useful in understanding Bona's strategy in constructing a conception of Frenchness which, while not typical, is a recognisable representation of twentieth century Hexagonal culture. ${ }^{11}$ The concept of tradition enables us to view culture as a process of connections whereby the present is legitimated through reference to a selective version of the past. Moreover, since it is linked to the lived experience of families and other groups, the process of incorporation not only shapes the present, but indicates directions for the future.

Bona uses tradition on two levels in Malika. The first of these is through her intertextual reference to Françoise Sagan's debut novel, Bonjour tristesse, with which Malika shares significant plot characteristics. ${ }^{12}$ Both novels are set on the Côte d'Azur, where a wealthy Parisian family has rented a luxurious secluded villa for the summer. Their leisurely rhythm is interrupted by the arrival of a character from outside (Anne Larsen and the eponymous Malika, respectively), whose presence challenges the family's values. Conflict ensues, together with various sexual adventures, before the interloper chooses to leave. Both novels conclude with a fatal car crash. Although brief, this summary should be sufficient to indicate that, in Malika, Bona is borrowing the structure of the earlier novel. In doing so, she is establishing a point of connection in which a version of the past is used to ratify the present: she is not only drawing on the literary tradition established by Sagan's provocative modern classic, but is using her reference to the earlier text as a shorthand means of communicating her interest in the same issues.

\footnotetext{
${ }^{9}$ Dominique Bona, Malika (Paris: Mercure de France, 1992). Page references will be given in the text.

10 John Clement Ball, Imagining London: Postcolonial Fiction and the Transnational Metropolis (Toronto: University of Toronto, 2004), p. 4.

${ }^{11}$ Williams, Marxism and Literature, p. 115.

12 Françoise Sagan, Bonjour tristesse (Paris: Julliard, 1954).
} 
Secondly, on a thematic level Bona, like Sagan, draws on the Parisian tradition of the summer holiday on the Côte d'Azur to signal the particular form of Frenchness upon which she is focusing. The annual move from Paris to the Mediterranean coast is a form of internal migration which reconstitutes the social network of bourgeois Parisians in the provinces, and so extends the centralising pull of the capital to the extremity of the Hexagon. By participating in the tradition, Parisians declare their membership of a particular bourgeois and centralised cultural group; by setting her narrative in this location, Bona communicates her concern with the same form of French culture which appeared in Sagan's 1954 novel.

Given Bona's use of Sagan as a model for her text, a brief overview of the narrative of Bonjour tristesse is necessary. The teenage narrator, Cécile, tells of how her world is turned upside down when a new arrival, Anne Larsen, joins the holiday group. While Cécile's family structure is unconventional, her dead mother's place being taken by a succession of her father's mistresses, Cécile is secure in her relationship with her father, and happy with the carefree, hedonistic lifestyle which they lead. The arrival of Anne affects the group on a number of levels. For Cécile, Anne is a threat to her independence, and a rival for her father's attention. On another level, Anne's status as an independent, divorced woman poses a challenge to Cécile's milieu, in which a woman's identity is constructed in relation to men, whether as daughter or mistress. Above all, with her sleek American convertible, Anne symbolizes the growing influence of American culture in years following $1945 .{ }^{13}$ The car symbolized the move towards speed, industrialization, and with it the rise of a global capitalism dominated by America, which threatened the French rural idyll, and exacerbated French anxieties about the loss of prestige associated with the end of empire. Seen as the exotic harbinger of consumerism, America was perceived ambivalently, as a source of threat and fascination which Bona reproduces by other means in Malika. The disruption to French culture emanating from beyond the Hexagon is therefore a source of anxiety neatly encapsulated by the arrival of Anne.

\footnotetext{
${ }^{13}$ For details, see Kristin Ross, Fast Cars, Clean Bodies: Decolonization and the Re-Ordering of French Culture (Cambridge, MA and London: Massachusetts Institute of Technology Press, 1995).
} 
Sagan is careful to nuance her representation, so that the conflict created by the arrival of Anne is not simply that of traditional bourgeois moeurs scandalised by newfangled American values. Although linked to the Americanisation of French society, with her insistence on comportment Anne is emblematic of French chic, her presence characterised by an elegant but detached refinement. Cécile and her father, in contrast, represent a superficial lifestyle which privileges fun and beauty over intelligence. Moreover, Cécile herself has been read as a disruptive influence within French society, given the novel's portrayal of her carefree sexual relationship. As her feelings towards Anne oscillate between resentment and a longing for approval and affection, her new sexual freedom, embraced in defiance of Anne's strictures, enables her to develop a degree of autonomy: '[S]ans doute craignis-je moins son influence depuis que j'aimais réellement et physiquement Cyril. Cela m'avait libérée de beaucoup de peurs'. ${ }^{14}$ It empowers her to manipulate her boyfriend, Cyril, to free herself from Anne's influence, and to drop Cyril when her manipulations are no longer necessary. Cécile's emerging sexuality is therefore a second manifestation of the cultural plurality which Bona also references in her novel. Although the influence of American culture is replaced by postcolonial immigration, the exotic ambivalence associated with extra-national cultures and feminine sexuality remains a potent focus of French anxiety. In Malika, these two aspects are combined in a single figure: the immigrant who represents the movement of the peripheries to the imperial centre.

\section{The nature and effects of disruption: exoticism in Malika}

Set in a St. Tropez villa, where a wealthy Parisian couple are on holiday with family and friends, Bona's novel opens on a world of contemporary bourgeois norms. The tradition of the Parisian summer holiday enables Bona to indicate the aspirations of her characters, whose public display of wealth is intended as a class indicator. The bourgeois love-affair with American sophistication continues, although Anne's convertible is now replaced by

\footnotetext{
${ }^{14}$ Sagan, Bonjour tristesse, p. 132.
} 
dinner party conversation peppered with English terms, and references to the delights of Florida. In a few pages, therefore, Bona swiftly constructs a Hexagon-centred world, whilst at the same time signalling that she shares Sagan's concern with cultural analysis. Ironically, given the importance of bourgeois values, the disruption which shakes the carefully orchestrated world comes from within, in the form of the family au pair. In contrast to Sagan's nuanced world, Bona makes a clear cultural distinction between the white French characters, and Malika. From the outset, she is presented as a solitary figure whose presence splits the reality of the villa and gives the reader access to 'un autre monde' (23). In spatial terms this other world is located to the rear of the house: an unseen domestic sphere of cooking and child-care. But there is also a metaphysical dimension to Malika's difference: early textual references to a lost world which she alone can see, and which she carries within her, convey overtones of mystery and primitivism, and endow her with a sense of the exotic. This insistence on the exotic proves fundamental to the cultural disruption which she causes.

As Kateryna Longley observes, exoticism is a politically and sexually charged form of othering which endows the exotic with 'a peculiarly alluring flavour, with suggestions of strange beauty, enticing difference and, most of all, the potential to be conquered and claimed' ${ }^{15}$ It draws on the Orientalist tradition, in which the difference of the Arab woman was perceived as a novelty, and valorised to the extent that it conformed to Western expectations of beauty, sensuality, and submissiveness. The exotic is associated with a certain ambivalence: the mystery of the Arab woman attracts and fascinates the Western onlooker but, in a parallel with French attitudes towards America, there is a fear of her power and difference. Historically, as Victor Segalen noted, the exotic has often been associated, even conflated, with the colonial, but the ambivalence of the exotic undermines the notion that power is located solely in the hands of the colonizer. ${ }^{16}$ According to Longley, the exotic wields its own slippery power, resisting Western attempts at totalizing discourses and escaping the categorisation produced by other Orientalist representations:

\footnotetext{
${ }^{15}$ Kateryna Olijnyk Longley, 'Fabricating Otherness: Demidenko and Exoticism', in 'New' Exoticisms: Changing Patterns in the Construction of Otherness, ed. by Isabel Santaolalla, Postmodern Studies, 29 (Amsterdam: Rodopi, 2000), pp. 21-39 (p. 23).

${ }^{16}$ Victor Segalen, Essai sur l'exotisme: une esthétique du divers (Montpellier: Fata Morgana, 1978), p. 81.
} 
The exotic [is] elusive and ungraspable, more slippery and less stably positioned than the 'oriental' and more capable of sliding away or striking back. The exotic is the sting in the tail of orientalism because it is the alluring and potentially entrapping aspect of otherness [...] Language and discourse always invent as much as 'record' their 'object' and the idea of 'containment' is a fiction. ${ }^{17}$

Longley's suggestion here is that the power of the exotic is potentially available to the exoticized subject, allowing her to escape or retaliate because she exceeds the orientalist discourses habitually used to refer to her. Because it is subversive in nature the power largely remains unseen, but it is hinted at in the references to the 'other world' to which Malika belongs.

Because Malika occupies the domestic sphere of the villa, the extent of her otherness is not immediately remarked upon by the Paul-Martin circle. Her arrival to serve dinner one night is striking, silencing the murmur of conversation:

La jeune fille rayonnait. Avec ses cheveux noirs très courts, ses dents de nacre, elle exprimait une merveilleuse jeunesse. Elle ne s'estompait pas comme Marie-Hélène l'eût souhaité, telle une figurante dans le décor. Au contraire. Elle avait l'éclat d'une star. De la soubrette, elle n'avait que le costume: une robe noire et un tablier blanc. La robe, à décolleté bateau, arrivait à mi-cuisses. Benoît Darman savourait du regard les jambes et les bras satinés, doux comme une peau d'abricot. Le tablier blanc avec le volant épinglé sur la poitrine à moitié visible ressemblait à un accessoire d'opérette. La jeune fille semblait jouer, être quelqu'un d'autre. Quelqu'un que personne ne connaissait, bien différent du rôle incertain et secondaire de servante qu'on lui attribuait. Quand elle se penchait, un curieux bijou en or, qui représentait une main, se détachait de ses seins ronds et se balançait audessus de l'hôte auquel elle présentait le plat.

La jeune fille fit en balançant des hanches le tout de la table, vivement, sans s'attarder, mais en se laissant contempler, sous tous les angles. Elle disparut. On fut bien incapable de reprendre la conversation là où on l'avait laissée (36-37).

Malika here is engaged in the performance of exoticism which calls into question the social context around her. Ostensibly focused on Malika and her silent and conscious use of what she knows to be her greatest asset - her body -, the incident acts as a catalyst which disturbs the equilibrium of the group and prompts them to re-evaluate their selfimage and that of their companions. The girl's appearance induces a process of decentring whereby the attention moves from a unified focus on the Centre, to a fragmented

${ }^{17}$ Longley, 'Fabricating Otherness', pp. 28-9. 
vision in which the Centre is seen only in relation to and as a reflection of the North African Other. The moment is a turning point in the novel; it establishes the social hierarchy between characters, confirming that, despite the differences in status, Malika dictates the responses of the other characters.

\section{Constructions of the exotic}

Malika's presence clearly destabilises those around her, but the precise form in which her exotic power manifests itself is worthy of analysis. The passage introduces the two elements primarily responsible: her sexuality, and her metaphysical beliefs, represented at the dinner table by the hand of Fatima pendant. Both are linked in the eyes of the French onlookers to her country of origin, and both play a key role in the novel, driving the narrative as it builds to the final, fatal climax. What is left deliberately vague is the source of Malika's exotic power. The exotic is constructed through the attributes of feminine sexuality and religious belief, but whether Malika's power resides in the perception of the French characters who are perturbed by her difference, or whether she indeed possesses an intensity which she can deploy at will remains ambiguous. An understanding of the causes of the de-centring which takes place in the novel therefore relies on analysis of the way in which the character of Malika is presented.

Throughout the novel, Malika's beauty and presence arrest the attention of all those around her. Instinctively, the French guests attribute this to her ethnic origins:

D'où pouvait-elle venir? Quel était son passé? De quel exotisme tirait-elle son étrange et fascinante beauté? Depuis le passage de l'inconnue, chacun demeurait sous l'emprise de son érotisme (38).

Her ethnicity is perceived as the source of her sexual attraction, and therefore of the disturbance which she creates in the St. Tropez holiday party. The women are threatened by her youth and dark beauty, finding their evening dress wanting when compared to the impossibly perfect skin and bare feet of the serving girl. The men respond to her eroticism in predictable ways, reproducing colonial attitudes of obsessive sexual desire in 
which Malika becomes a post-Flaubertian version of Kuchuk Hanem. While she appears to offer a convenient taste of the Orient for consumption in France, those men who pursue her as a prize to be taken find that consummation, rather than satiating their desire, only makes it more urgent.

Initially, in giving herself sexually, Malika appears to be subject to the traditional exploitation of the colonial woman, but she confounds the tradition of the passive odalisque by exerting her own control over her male admirers/exploiters. By remaining consistently aloof, she maintains the distance necessary to her exotic aura which, because it is dependent on the novelty of perceived difference, would be diminished by familiarity. Cultivating her independence as a free spirit, she is prone to leave without warning, as her lovers quickly discover. Each man learns to negotiate his apparent powerlessness in the face of the emasculation threatened by Malika's appropriation of her own subjectivity. Her elusiveness adds to her fascination, since her actions seem dictated by some unseen higher power. The power of her sexuality is therefore linked to the other disturbing aspect of her presence - her religious belief - for in leaving her lovers, Malika is responding to her sense of individual destiny.

Malika's religious belief is complex, drawing on a web of influences. She comes from a Muslim village where her family, with the exception of her Berber grandmother, follow Islamic principles. Rejecting the practices of Islam as the imposition of conformity, Malika is drawn to the magic and pagan rites of her grandmother, from whom she learns to pray to the stars and how to attract the protection of the marabout. While Malika is dismissive of the outward signs of Islam, she accepts its emphasis on fatalism and believes fervently in her own destiny - the Arabic 'mekhtoub' - as set out by the stars. Her unique perspective manifests itself through references to the hidden 'other world', while her unswerving belief in what she sees as a deeper, more authentic pagan faith enables her to endure exploitation by others in the knowledge that she is following the path set out for her. The hand of Fatima, which she wears around her neck, symbolises the sometimes sinister air of magic which surrounds her, and which disconcerts others, who refer to her as 'Esmeralda' (181) or 'l'ensorceleuse' (194) who casts a spell over the men around her. Malika is thus set apart even from those closest to her, including her sisters, who believe that she can bring misfortune to those who wrong 
her. Bona emphasises Malika's sense of otherworldliness by having her story narrated by a character known as 'la voyante'. Despite a career which demands a familiarity with the magical, the fortune-teller confesses that she has never before encountered a presence like Malika's.

Through repeated references to the growing sense of unease, and the suspicion that Malika has cast a spell on the group, Bona encourages the reader to take at face value the disruptive potential of Malika's exoticism. However, in parallel with the sexual fantasies and suspicions of magic to which she gives rise, the narrative contains traces which indicate alternative causes of the disruption. The response of David, her French employer, demonstrates most clearly the link between Malika's sexual presence and her ethnic origins, for in addition to exciting David's sexual fantasies, her presence brings back painful, repressed memories of his pied noir childhood. These memories, like 'des esprits malins, sournois, qui venaient troubler sa paix' (43), are compounded by his son Jérémie's use of the Arabic term 'sidi papa', which disturbs David because it recalls the unhappiness of another era, and provides evidence that, far from being lost, this era is alive and influencing the next generation. His wife, Marie-Hélène, shares his reaction when she stumbles across her two young children making an offering of stones collected on the beach, as part of a mystical rite led by Malika. Through specific examples, Bona thus depicts the doubts and anxiety of the Français de souche when faced with the presence of North African immigrants and their culture in metropolitan France. She represents the vestiges of colonial attitudes amongst a privileged section of mainstream French society which has turned its back on its past relationship with North Africa, repressing the memories of its time there, and refusing to acknowledge the legacy of decolonisation. However, paradoxically, it may be that the refusal of the white middleclasses to come to terms with their past is responsible for attributing power to Malika. The perceptions of Malika are so coloured by colonial stereotyping that it is difficult for the French characters to move beyond them, to see her in a new light as a young immigrant girl who speaks little French. 


\section{The exotic: alternative sources of power}

The persistence of colonial thought contributes towards the possibility that the disturbance which accompanies Malika may not be the result of any power immanent in her. On one level, Malika appears to wield the power of the elusive and exotic object referred to by Longley. She achieves a degree of recognition through a photographic career as a model, but is dismissive of its material rewards. She prefers to maintain her freedom on her own terms, accepting the attentions of her lovers but liable to disappear without warning. Having followed her destiny to France, she chooses to remain distanced from the French society within which she finds herself. However, the conclusion that, as an Arab immigrant, Malika possesses the ability to de-centre French society through her presence is less than convincing. As an unstable, subjective category, the exotic is dependent on the perspective of the spectator; as Longley says, because it is always an attribute given to someone else, exoticism, like orientalism, is a way of seeing which sustains the myth of the cultural centrality, and therefore the superiority, of the viewer. ${ }^{18}$ On closer examination, Malika's exotic power can be seen as having been constructed by Bona to fit contemporary Western expectations of the Oriental woman, and provide a modern odalisque suitable for consumption by a Western audience. The consequent decentring of white French culture which takes place in the novel is therefore less the result of any power inherent in Malika, than of the traces of Western discourse and prejudice made evident through the reactions of other characters.

Various aspects contribute to the construction of the exotic, beginning with the choice of a female protagonist. Femininity and female sexuality have traditionally featured strongly in literary and artistic representations since, as feminists have noted, Woman occupies a position as 'the prime representative of difference'. ${ }^{19}$ As we have seen, Malika enjoys an idealised Oriental beauty and, with her bare feet and haughty demeanour, her appearance communicates a pride and disdain reminiscent of the portrayals of defiant Algerian women forcibly unveiled by French soldiers during the

\footnotetext{
${ }^{18}$ Longley, 'Constructing Otherness', p. 23.

${ }^{19}$ Valérie Orlando, Nomadic Voices of Nomadic Voices of Exile: Feminine Identity in Francophone Literature of the Maghreb (Athens: Ohio University Press, 1999), p. 17.
} 
Algerian War. She inhabits an ambivalent space with regard to the white French characters, finely balanced between the domestic banality of the villa, the social world of its guests, and an exotic and undefined metaphysical 'other world', while as a girl barely past adolescence, she occupies the liminal space between child and adult. Since the exotic is a representation of difference translated for the spectator, her interstitial position crucially allows her difference to be comprehensible to her French onlookers.

The aloofness that so attracts Malika's lovers is another instance of the ambivalence of the exotic. Despite being the novel's protagonist, she remains silent throughout the novel, and is accorded no direct or even reported speech. This could be attributed to her lack of French, since the narrator tells us that she learns the language with difficulty some time after her arrival in the country. However, it reinforces the assumption that, because the exotic cannot speak for itself, it must be spoken for. Moreover, Bona uses Malika's silence to emphasise her mystery. According to the clairvoyant, whose first-person narrative retells Malika's story, the other characters are kept at a distance from Malika, who deliberately maintains her enigmatic persona in her relationships with others by restricting their access to different aspects of her life:

Personne parmi ceux qui ont croisé sa route - sauf moi peut-être qui tente de rassembler nos souvenirs éparpillés - n'a connu Malika dans son unité. On croyait la connaître et pourtant elle nous échappait toujours, ne donnant chaque fois qu'une part d'elle-même, une pièce plus ou moins originale du puzzle de sa vie (214).

The fragmented nature of this reported story, based on Malika's recollections of her childhood, recounted years after her arrival in France and supplemented by the findings of the narrator's own investigations, introduces layers of unreliability into the narrative and effectively distances reader from subject.

The distance and mystery created by Malika's self-conscious reticence plays a major role in leading other characters to perceive her as exotic and different. In his Essai sur l'exotisme, Segalen argues that individualism is an essential component of the exotic: 
L'exotisme n'est donc pas cet état kaléidoscopique du touriste et du médiocre spectateur, mais la réaction vive et curieuse au choc d'une individualité forte contre une objectivité dont elle perçoit et déguste la distance. ${ }^{20}$

With a swipe at the tourist collective, Segalen emphasises the need for individualism on the part of the observer. Bona's novel, however, suggests that the difference which sets Malika apart is linked to her individuality, indicating that this element also has an important role to play in the construction of the exoticised subject. The rise of individualism in the exotic can arguably be traced to the development of modernity. As Zygmunt Bauman maintains, the erosion of community and family structures which characterised earlier periods has produced an atomised society which emphasises the discrete unit. Contemporary society is characterized by fluidity, with individuals working to create their own identity in locations which owe more to the demands of the labour market than to their place of birth or family residence so that, as Bauman argues, 'to speak of individualization and of modernity is to speak of one and the same social condition'. ${ }^{21}$ With Westerners now more attuned to individual rather than collective identity and difference, contemporary exoticism has evolved such that the status of the exotic is less attributable to a mass of undifferentiated groups or communities. A representation of the objective differences between North African and French society might emphasise the importance of the extended family or the nomadic tribe. In contrast, Bona is careful to insist on a separation between Malika, and her family and neighbours, who regard her as different and set apart. In doing so, she demonstrates that, although a contributory factor, ethnicity alone is not sufficient to render a subject exotic.

Religion, and more precisely, Malika's personal faith in her destiny, offers another means of exotic differentiation. While the exact form of her belief is strange to the French characters around her, the idea of an individual religion is appealing because the notion that religion, or the metaphysical, is something which belongs to the private sphere is a peculiarly Western view. In contrast, Bona's representation of Islam conforms to the contemporary media construction of it as a religion incommensurate with French

\footnotetext{
${ }^{20}$ Segalen, Essai sur l'exotisme, p. 25.

21 Zygmunt Bauman, Liquid Modernity (Cambridge: Polity, 2000), p. 32.
} 
secular norms; ${ }^{22}$ it is shown in a negative light as a cultural imposition which refuses any division between public and private. Malika's rejection of the dominant North African religion in favour of Berber religious practice - which can be seen as 'the Other of the (Islamic) Other' - can be read as another move towards social disruption, as an attempt to counter the hegemony of Arabization imposed by North African governments, and reclaim the diversity of pre-colonial Maghrebi culture. However, given that Berbers generally follow Islam, the reference to the grandmother's pagan beliefs can be seen as an instance of French imperialist nostalgia for an authentic primitive culture, a phenomenon which has become increasingly important to contemporary constructions of exoticism. ${ }^{23}$ It also reinforces the colonial stereotype of the Berber as being ethnically closer to the French, and therefore potentially more assimilable than the Arab, downplaying the threat presented by Malika while maintaining her enticing sense of difference.

Malika's belief thus becomes a site of liminality, distancing her from the putative 'clash of civilizations', and bringing her closer to a style of religion which, although alien to French culture in content, conforms to Western tastes in terms of form. ${ }^{24}$ Despite ongoing debates about the place of religion in public life, Western forms of religion remain overwhelmingly confined to the private sphere, with restricted public influence. The character of Malika conforms to this tendency, offering a brand of personal fate which forms part of what bell hooks has criticised as the 'spice' of the Other, whilst not conflicting with the secular norms of modernity. ${ }^{25}$ Although often mysterious to the West, with its emphasis on the collective worldwide umma Islam is not a religion of individualism, and so resists the tendency towards exoticism.

Analysis of the various aspects of the character of Malika, such as gender, physical appearance, age, individual solitude, and personal religion, indicates that she

\footnotetext{
22 Paul Silverstein, Algeria in France: Transpolitics, Race, and Nation (Bloomington: Indiana University Press, 2004), p. 58.

${ }^{23}$ For analysis of 'imperialist nostalgia', see Renato Rosaldo, Culture and Truth: The Remaking of Social Analysis (Boston, MA: Beacon, 1989), pp. 69-70.

${ }^{24}$ Samuel P. Huntington, The Clash of Civilizations and the Remaking of World Order (London: Touchstone, 1998).

${ }^{25}$ bell hooks, 'Eating the Other: Desire and Resistance', in Black Looks: Race and Representation (Boston, MA: South End, 1992), pp. 21-39.
} 
conforms to modern Western expectations of exoticism. This effectively undermines the claim that she appears to 'exceed' the norms and conventions of French society, and appropriates the power which her exoticism makes available. Instead, the power which she apparently wields, for example, to leave without warning, simply shows her to be operating according to the ideals of Bauman's liquid modernity, allowing the flow of power to move unhindered by ties of family or other commitments. In light of this, Malika can be read simply as an exoticized version of the conventional Bildungsroman liberal subject. The disruption which accompanies her is less the result of any inherent power, than a consequence of the exoticising expectations and colonial attitudes of the French characters and, potentially the implied French reader, which are projected onto her.

\section{Consequences of disruption}

Nonetheless, regardless of its source, Malika's presence effectively disturbs and de-centres the white French society which surrounds her. The overall effect on the group is the impression of a gathering metaphorical storm which grows nearer as the summer progresses, and which transforms into a physical thunderstorm in the dénouement. In Bonjour tristesse, the dénouement is triggered by Cécile's manipulations: like a Racinian tragedy, once set in motion, her plans for Cyril and Elsa gain a momentum which inevitably leads to a climax. The ambiguity around Anne's fatal car crash, which may have been suicide or accident, problematises the question of control. Cécile succeeds in her apparent aim of forcing Anne to leave; she repels the intruder who threatens her independence and way of life, but the extent to which Anne decides the manner of her leaving is left open. The question of whether Anne truly posed a threat to Cécile's world is left similarly vague; Cécile realises at the moment of Anne's departure that her fight was not against a pitiless force, but against another human being with whose hopes she can empathise. Happily for Cécile, the disturbance to her way of life appears to be temporary. But as postcolonial theorists have shown, the effects of cultural interaction cannot be reversed; once a new cultural element has been introduced it may be 
incorporated, but a return to the status quo is impossible. While the final climax is succeeded by Cécile's assertion that 'La vie recommença comme avant ${ }^{26}$, the closing paragraphs of the narrative, with their famous reference to the 'tristesse' of the title, indicate that the margins of her daily life remain marked by traces of what has taken place. Order is restored, with the proviso that the imagined unity of cultural experience, always illusory, has been exposed once more.

While Sagan sowed the seeds of her dénouement in the actions of her heroine, Bona's climax builds through the growing sense of unease. However, in parallel to the impression of impending disaster, each of the French characters become drawn towards elements outside of their everyday life. The practical de-centring of their lives also appears to be indirectly linked to the au pair, but in contrast, it manifests itself positively in a new sense of creativity. It inspires a complete volte-face from the architect, Benoit Darmon, who abandons the clean lines of glass and steel which have been his trademark design, to conceive his new collection in a decadent, oriental style which will bring him commercial success and critical renown. His change in direction thoroughly unsettles Benoît's hostess and design client, Marie-Hélène, for whom it represents an artistic betrayal. Nonetheless, Marie-Hélène also finds herself drawn to explore her own artistic leanings, and embarks on painting and sculpture which enables her to develop her individual creativity, outside the roles of design manager, wife, hostess and mother which have defined her previously. Malika thus brings associations which are both threatening and empowering: at the conclusion of the novel, each of the French characters is energised to enter a new and constructive phase of their lives.

The positive consequences of Malika's stay raise the question of whether the sense of threat occasioned by her disruptive presence is justified, a point underlined by the way in which events are brought to a head. The catalyst for the dénouement is in fact unrelated to Malika: it is borrowed straight from Sagan, in the form of a car crash which kills one of the minor characters, a woman called Élizabeth who barely features in the narrative. Her death forces each character to reassess their situation. It also coincides with Malika's unannounced departure from the villa. Unlike Anne, she is fully in control of

\footnotetext{
${ }^{26}$ Sagan, Bonjour tristesse, p. 153.
} 
the moment and manner of her leaving, an event which, because it passes unnoticed, has little bearing on the other characters. Instead, the narrative concludes in the manner of Sagan's, projecting forward into the future of each French character. The summer is revealed to have been a turning point, in which each has learnt 'une certaine forme de vérité' (336) which moves them on to the next stage of their lives. Unlike the conclusion of Sagan's narrative, there is no suggestion of a lingering sadness; despite the threatening atmosphere, the summer has been overwhelmingly an empowering experience.

The positive conclusion of Bona's novel, in contrast to the ambivalence of Cécile's narrative, calls for a reassessment of the disruption which Malika's presence occasions. As an Arab immigrant, she is expected to remain in the background, but instead her beauty and sexuality makes her the focus of the holiday group. Her ethnicity brings with it unresolved memories of French colonialism, and the persistent residue of Orientalist thought. While the French characters experience her presence as a threat and disruption to their social structure, analysis indicates that the power attributed to the girl by these attitudes is less an inherent quality which she possesses than the result of colonial stereotypes which, projected onto her, influence the behaviour of those around her. Ultimately the threat associated with the ambivalence of the exotic and linked to the 'reinvasion of the centre' is revealed to be empty. The de-centring which takes place is therefore revelatory of contemporary French social mores, rather than of any perceived power latent in a young immigrant girl.

Taken together, Sagan and Bona's novels demonstrate that the challenge to hegemonic culture which is periodically posed by extra-national movements often creates only a temporary disruption before being recuperated into the dominant narrative, leaving only traces. In this process, however, such moments of cultural disruption serve to expose the plural nature of the apparently dominant, and turn the critical gaze upon French culture, calling for a reassessment of French values, norms, and attitudes towards otherness. By drawing on Bonjour tristesse as intertext, Bona constructs a powerful representation of bourgeois society, and so represents the de-centring effects of immigration whilst refusing to bow to contemporary anxieties about the consequences for French culture. In doing so, she illustrates the ability of the novelist to engage, albeit in a 
literary rather than a theoretical mode, with the issues of postcoloniality present in the Hexagon which, to date, have been neglected by French scholars working in other fields.

\section{Bibliography}

Ball, John Clement, Imagining London: Postcolonial Fiction and the Transnational Metropolis (Toronto: University of Toronto, 2004).

Bauman, Zygmunt, Liquid Modernity (Cambridge: Polity, 2000).

Bhabha, Homi K., 'The Other Question: Difference, Discrimination and the Discourse of Colonialism,' in Literature, Politics and Theory: Papers from the Essex Conference 1976-84, pp. 210-229, ed. by Francis Barker, Peter Hulme, Margaret Iversen and Diana Loxley (London \& New York: Methuen, 1986).

Bona, Dominique Malika (Paris: Mercure de France, 1992).

Forsdick, Charles, 'Colonial history, postcolonial memory: contemporary perspectives', Francophone Postcolonial Studies, 5.2 (2007), 101-118.

------, and David Murphy, eds, 'France in a Postcolonial Europe: history, memory, identity', special issue of Francophone Postcolonial Studies, 5.2 (Autumn/Winter 2007).

------, and David Murphy, eds, Francophone Postcolonial Studies: A Critical Introduction (London: Arnold, 2003).

Hargreaves, Alec G., and Mark McKinney, eds, Post-colonial Cultures in France (London: Routledge, 1997).

hooks, bell, 'Eating the Other: Desire and Resistance', in Black Looks: Race and Representation (Boston, MA: South End, 1992), pp. 21-39.

Huntington, Samuel P., The Clash of Civilizations and the Remaking of World Order (London: Touchstone, 1998).

Longley, Kateryna Olijnyk, 'Fabricating Otherness: Demidenko and Exoticism', in 'New' Exoticisms: Changing Patterns in the Construction of Otherness, ed. by Isabel Santaolalla, Postmodern Studies, 29 (Amsterdam: Rodopi, 2000), pp. 21-39.

Murphy, David, and Alec G. Hargreaves, 'New Directions in Postcolonial Studies', special issue of Journal of Postcolonial Writing, 44.3 (Sept 2008).

Orlando, Valérie, Nomadic Voices of Nomadic Voices of Exile: Feminine Identity in Francophone Literature of the Maghreb (Athens: Ohio University Press, 1999).

Rosaldo, Renato, Culture and Truth: The Remaking of Social Analysis (Boston, MA: Beacon, 1989).

Ross, Kristin, Fast Cars, Clean Bodies: Decolonization and the Re-Ordering of French Culture (Cambridge, MA and London: Massachusetts Institute of Technology Press, 1995).

Sagan, Françoise, Bonjour tristesse (Paris: Julliard, 1954).

Segalen, Victor, Essai sur l'exotisme: une esthétique du divers (Montpellier: Fata Morgana, 1978).

Silverstein Paul, Algeria in France: Transpolitics, Race, and Nation (Bloomington: Indiana University Press, 2004), p. 58.

Williams, Raymond, Marxism and Literature (Oxford: Oxford University Press, 1977). 